Situs Jurnal : $\underline{\text { http://ejurnal.stiepancasetia.ac.id/index.php/jieb }}$

Jilid 4 Nomor 2 Juli 2018

Hal $202-215$

\title{
ANALISIS PENGARUH MOTIVASI KERJA, KOMPETENSI, DAN KOMPENSASI TERHADAP KINERJA ANGGOTA KEPOLISIAN DI UNIT KERJA POLRES KAPUAS PROVINSI KALIMANTAN TENGAH
}

\section{Siswono Tri Soemantri \& Nurus Sjamsi*}

Abstract: The purposes of this research are to investigate and analyze the effect of work motivation, competency, and compensation both simultaneously and partially on the performance of the police officers working in the police department of Kapuas, Kalimantan Tengah province. The method of research is descriptive and the how independent variables affect dependent ones, is reviewed. Therefore, our research is explanatory research. The number of populations employed in this research is 185 polices. The samples are taken based on random sampling method with the sample size $30 \%$ of the population. Therefore, the number of samples is 55 polices. The instrument of research is tested with validity and reliability test, and the data are tested with double linear regression. The research proves that the work motivation, competency and compensation affect simultaneously and partially to the performance of the police officers. The work motivation has the dominant effect on the performance of the police officers in the police department of Kapuas, Kalimantan Tengah province.

Keywords: work motivation, competency, compensation, performance.

Abstrak: Tujuan dari penelitian ini adalah untuk menyelidiki dan menganalisis dampak dari motivasi kerja, kompetensi, dan kompensasi baik secara simultan maupun parsial terhadap kinerja petugas polisi di POLRES Kapuas Provinsi Kalimantan Tengah. Metode penelitian yang digunakan adalah metode deskriptif dan mereview bagaimana variabel dependen dipengaruhi oleh variabel independen. Oleh karena itu, penelitian ini termasuk jenis penelitian eksplanatori. Populasi dari penelitian ini adalah 185 orang polisi. Sampel diambil menggunakan teknik sampel acak sebanyak 30\% dari populasi, yaitu 55 polisi. Instrumen penelitian diuji validitas dan reliabilitasnya, dan data diuji menggunakan regresi linear berganda. Penelitian ini membuktikan bahwa motivasi kerja, kompetensi, dan kompensasi secara simultan maupun parsial mempengaruhi kinerja polisi. Motivasi kerja memiliki pengaruh yang dominan terhadap kinerja polisi di POLRES Kapuas Provinsi Kalimantan Tengah.

Kata kunci : motivasi kerja, kompetensi, kompensasi, kinerja

\section{Latar Belakang}

Sumber daya manusia merupakan tokoh sentral dalam organisasi maupun perusahaan, termasuk organisasi Kepolisian Republik Indonesia. Semakin tinggi kemampuan anggota Kepolisian, semakin tinggi pula kinerja organisasi. Sebaliknya semakin rendah kemampuan anggota Kepolisian, maka semakin rendah pula kinerja organisasi.

Strategi pengembangan sumber daya manusia juga menyangkut masalah kompetensi dalam kemampuan teknis, konseptual, dan hubungan manusia. Pengelolaan kompetensi 
tenaga kerja meliputi beberapa kompetensi seperti : kompetensi berbasis input, kompetensi transformasional, kompetensi output (Rivai, 2004).

Pengaruh kompetensi pada kinerja dapat dilihat dari tingkat kompetensinya yang mempunyai implikasi praktis dalam perencanaan sumber daya manusia, hal ini dapat dilihat dari gambaran bahwa kompetensi pengetahuan dan keahlian cendrung lebih nyata dan relatif lebih terlihat dipermukaan,sebagai salah satu karakteristik yang dimiliki anggota Kepolisian.

Agar organisasi atau lembaga pemerintahan termasuk Kepolisian dapat berkembang luas dengan segala kegiatan-kegiatan yang dilakukan untuk mencapai tujuan yang diinginkan dengan menggunakan sumber daya manusia yang tersedia, namun untuk mencapai tujuan tersebut,tidak cukup hanya dengan jalan memperoleh anggota yang dianggap paling kompeten, akan tetapi tidak kalah pentingnya adalah motivasi yang secara terus menerus diberikan oleh pimpinan. Variabel lain yang juga memengaruhi adalah kompensasi, dimana kompensasi yang memuaskan menjadikan anggota kepolisian lebih bersemangat dalam menjalankan tugas-tugasnya di organisasi.

Dimilikinya sumber daya manusia yang berkualitas diharapkan mampu menghasilkan produktivitas kerja yang baik. Pada kenyataannya masih banyak instansi yang belum bisa menciptakan produktivitas kerja yang optimal sesuai dengan apa yang diharapkan. Hal ini dapat di lihat dari berbagai sudut pandang, antara lain dari karyawan. Motivasi diri yang kurang mendukung untuk menciptakan kinerja yang kurang optimal. Di sisi lain terdapat masalah reward, masalah kompensasi, budaya dari organisasi tersebut yang menjadi sumber motivasi untuk peningkatan kinerja pegawai (Muniroh, 2013).

Selain motivasi, kompetensi dan kompensasi yang juga menentukan kinerja seseorang adalah kepuaan kerja.Kepuasan kerja merupakan suatu hal yang berhubungan dengan kepuasan individu dalam melakukan pekerjaannya. Setiap individu memiliki kepuasan kerja yang berbeda-beda sesuai dengan keinginan dan system yang dianutnya. Karyawan yang tidak memperoleh kepuasanan kerja maka biasanya tidak mencapai kematangan psikologis. Karyawan yang mempunyai kepuasan kerja yang baik akan memberikan suatu catatan kinerja yang baik seperti catatan kehadiran, perputaran kerja dan prestasi kerja yang baik dibandingkan dengan karyawan yang tidak mendapatkan kepuasan kerja. Kepuasan kerja juga dapat dipengaruhi oleh kompensasi yang diberikan oleh instansi kepada karyawannya (Suparno, 2007).

Kompensasi merupakan sistem balas jasa yang dapat dilihat sebagai suatu sistem yang berada pada hubungan timbal balik antara instansi dengan karyawan. Setiap instansi mempunyai berbagai jenis kompensasi untuk menarik, mem pertahankan orang-orang serta memotivasi mereka agar bekerja sesuai dengan tujuan instansi. Diharapkan dengan memberikan kompensasi, dapat berdampak terciptanya iklim kerja yang kondusif yang dapat menghasilkan pekerjaan yang lebih banyak dan lebih baik sesuai yang diharapkan.

Berdasarkan data yang didapatkan di POLRES Kapuas dalam hal penilaian kinerja 185 orang anggota kepolisisnan yang berpangkat Brigadir dari bulan Januari - Nopember 2017, dapat dilihat pada Tabel 1.

\section{Tabel 1. Penilaian Kinerja Anggota Kepolisian POLRES Kapuas Januari - Nopember} 2017

\begin{tabular}{clcc}
\hline No & \multicolumn{1}{c}{ Predikat Kerja } & Jumlah & Persentase (\%) \\
\hline 1. & Baik Sekali & 63 & 34,0 \\
\hline 2. & Baik & 79 & 42,7 \\
\hline 3. & Cukup & 31 & 16,8 \\
\hline 4. & Kurang & 12 & 6,5 \\
\hline & & 185 & 100,0 \\
\hline
\end{tabular}


Melihat penilaian kinerja anggota Kepolisian di POLRES Kapuas di atas secara menyeluruh sudah tergolong baik, namun demikian masih anda anggota yang kinerjanya cukup, bahkan masih ada yang kurang. Hal ini perlu mendapatkan perhatian dan perkerjaan rumah bagi pimpinan untuk merubah kinerja agar mereka menjadi lebih baik, sehingga penilaian masyarakat terhadap Kepolisian menjadi lebih baik. Untuk itu semua diperlukan suatu terobosan oleh pimpinan untuk menciptakan kinerja yang baik tersebut, misalnya dengan memotivasi anggota, memberikan suatu kompensasi walaupun tidak selalu berbentuk materi, misalnya sanjungan, ucapan selamat ataupun memberikan peluang untuk mengikuti pendidikan yang lebih tinggi.

Berdasarkan pada fakta-fakta yang ada dan atas beratnya tugas pokok Kepolisian sebagai pemelihara keamanan, ketertiban masyarakat serta penegak hukum untuk memberikan perlindungan, pengayom dan pelayanan kepada masyarakat di wilayah hukum Kabupaten Kapuas, tentunya akan bersentuhan langsung dengan masyarakat. Maka pihak Kepolisian dituntut untuk memberikan pelayanan secara profesional dan memegang kode etik sehingga akan memberikan citra yang baik di masyarakat dan selalu dihadapkan pada fenomena-fenomena baru seiring dengan terjadinya berbagai perubahan pola kehidupan sosial masyarakatnya.

Agar tujuan penelitian dapat tercapai dan permasalahan yang akan dibahas menjadi lebih terarah, maka perlu dilakukan identifikasi dan spesifikasi masalah yang akan diteliti dan dibahas dalam penelitian dan rumusan masalah adalah :

1. Apakah motivasi kerja, kompetensi dan kompensasi berpengaruh secara simultan terhadap kinerja anggota Kepolisian di unit kerja POLRES Kapuas Provinsi Kalimantan Tengah ?

2. Apakah motivasi kerja, kompentensi dan kompensasi berpengaruh secara parsial terhadap kinerja anggota Kepolisian di unit kerja POLRES Kapuas Provinsi Kalimantan Tengah ?

3. Manakah dari variabel motivasi kerja, kompetensi dan kompensasi yang berpengaruh dominan terhadap kinerja anggota Kepolisian di unit kerja POLRES Kapuas Provinsi Kalimantan Tengah?

\section{Kajian Literatur}

Manusia sebagai salah satu komponen dasar di dalam organisasi publik harus memiliki motivasi yang tersimpan didalam hati atau keinginannya yang dapat memacu untuk meraih apa yang dicita-citakan. Motivasi adalah konsep yang menguraikan tentang kekuatankekuatan yang ada dalam diri karyawan yang memulai dan dapat mengarahkan perilaku orang tersebut (Gibson, Ivancevich dan Donnely, 2004).

Motivasi kerja adalah dorongan, upaya dan keinginan yang ada dalam diri manusia yang mengaktifkan, memberi daya serta mengarahkan perilaku dalam pelaksanaan tugas di lingkungan pekerjaannya. Hakikat dari motivasi kerja adalah dorongan untuk melakukan segala sesuatu dengan lebih baik dari yang lainnya dalam melakukan kegiatan untuk mencapai tujuan (Husein Umar, 2002). Motivasi merupakan hasrat di dalam diri seseorang yang menyebabkan orang tersebut melakukan tindakan (Malthis, R. L. dan Jackson, 2001).

Berdasarkan pengertian di atas dapat disimpulkan bahwa motivasi kerja merupakan kegiatan yang mengakibatkan, menyalurkan, memelihara, dan mendorong perilaku seseorang untuk melakukan suatu perbuatan atau tindakan tertentu secara optimal untuk mencapai apa yang menjadi sasaran.

Konsep kompetensi mulai menjadi trend dan banyak dibicarakan dan saat ini menjadi sangat populer terutama dilingkungan perusahaan multinasional dan nasional yang "modern". Istilah dan konsep competency sebenarnya telah diperkenalkan seorang penulis manajemen Amerika Serikat dalam buku The Competence Manager. Dalam buku tersebut Boyatzis menyampaikan dalil bahwa manajer bisnis Amerika Serikat harus memiliki kompetensi 
tertentu bila bisnis dan ekonomi Amerika Serikat tidak ingin dikalahkan Jepang dan Eropa (Ruky. A.S, 2006).

Beberapa pengertian kompetensi antara lain:

1. Kompetensi berasal dari bahasa Inggris competency yang berarti a) kecakapan, kemampuan, kompetensi; b) wewenang (John M. Echols dan Hasan Shadily,1975).

2. Kompetensi adalah suatu kemampuan untuk melaksanakan suatu pekerjaan atau tugas yang dilandasi atas ketrampilan dan pengetahuan serta didukung oleh sikap kerja yang dituntut oleh pekerjaan tersebut (Wibowo, 2008). Selanjutnya dikatakan bahwa konsep diri adalah sikap, nilai-nilai atau citra diri seseorang. Percaya diri merupakan keyakinan orang bahwa mereka dapat efektif dalam hampir setiap situasi adalah bagian dari konsep diri orang. Pengetahuan adalah informasi yang dimiliki orang dalam bidang spesifik. Pengetahuan adalah kompetensi yang kompleks. Ketrampilan adalah kemampuan mengerjakan tugas fisik atau mental tertentu. Kompetensi mental atau ketrampilan kognitif termasuk berpikir analitis dan konseptual.

3. Kompetensi sebagai karakteristik dari seseorang yang dapat diperlihatkan, yang meliputi pengetahuan, ketrampilan, dan perilaku, yang dapat menghasilkan kinerja dan prestasi (Dessler, 2006). Kompetensi, keahlian, dan pengetahuan yang terukur adalah inti dari proses manajemen kinerja di semua perusahaan atau instansi.

4. "An underlying characteristic of an individual that is casually related tocreterion referenced effective and/or superior performance in a job orsituation" atau kompetensi adalah karakteristik dasar seseorang (individu) yang mempengaruhi cara berfikir dan bertindak, membuat generalisasi terhadap segala situasi yang dihadapi serta bertahan cukup lama dalam diri manusia.

5. Kompetensi berorientasi pekerjaan adalah kemampuan, perilaku atau ketrampilan yang telah diperlihatkan untuk menimbulkan atau memprediksi kinerja unggul dalam pekerjaan tertentu (Rampesad, 2006).

Pada dasarnya manusia bekerja juga ingin memperoleh uang untuk memenuhi kebutuhan hidupnya. Untuk itulah seorang karyawan mulai menghargai kerja keras dan semakin menunjukkan loyalitas terhadap perusahaan dan karena itulah perusahaan memberikan penghargaan terhadap prestasi kerja karyawan yaitu dengan memberikan kompensasi. Salah satu cara manajemen untuk meningkatkan prestasi kerja, memotivasi dan meningkatkan kinerja para karyawan adalah melalui kompensasi (Malthis, dan Jackson, 2001).

Kompensasi penting bagi karyawan sebagai individu karena besarnya kompensasi mencerminkan ukuran karya mereka diantara para karyawan itu sendiri, keluarga dan masyarakat. Kompensasi acapkali juga disebut penghargaan dan dapat didefinisikan sebagai setiap bentuk penghargaan yang diberikan kepada karyawan sebagai balas jasa atas kontribusi yang mereka berikan kepada organisasi (Panggabean, 2002).

Tujuan manajemen kompensasi adalah untuk membantu organisasi mencapai keberhasilan strategis sambil memastikan keadilan internal dan eksternal. Internal equity atau keadilan internal memastikan bahwa jabatan yang lebih menantang atau orang yang mempunyai kualifikasi lebih baik dalam organisasi dibayar lebih tinggi. Sementara itu, external equity atau keadilan eksternal menjamin bahwa pekerjaan mendapatkan kompensasi secara adil dalam perbandingan dengan pekerjaan yang sama di pasar tenaga kerjanya.

\section{Metode Penelitian}

Penelitian dilakukan di wilayah hukum Polres Kapuas Provinsi Kalimantan Tengah. Dalam Penelitian atau rancangan yang digunakan desain deskriptif dan dilakukan pula penelaahan hubungan antara variabel (desain kausal) yang berguna untuk mengukur 
hubungan antara variabel riset atau untuk menganalisis bagaimana pengaruh suatu variabel terhadap variabel lainnya, sehingga jenis penelititan ini termasuk penelitian eksplanatory. Dalam penelitian ini data dihimpun secara ex post facto, dengan kata lain peneliti mengandalkan pada persepsi responden untuk menerangkan pengalaman-pengalamannya dan selanjutnya dianalisis menurut desaian deskriptif dan kausal.

Penelitian ini, terdiri dari tiga variabel independen dan satu variabel dependen. Tiga variabel bebas tersebut masing-masing adalah motivasi kerja (X1), kompetensi (X2), dan kompensasi (X3). Sedangkan variabel tidak bebas adalah kinerja anggota Kepolisian di unit kerja Polres Kapuas (Y).

Populasi dalam penelitian ini anggota Kepolisian Polres Kapuas berpangkat Brigadir, sebagai polisi yang melaksanakan tugas sehari-hari, yaitu berjumlah sebanyak 185 orang. Sampel diambil berdasarkan teknik random sampling yang dikemukakan oleh Arikunto (1998), ukuran sampel penelitian adalah $30 \%$ dari jumlah populasi. Besar sampel dalam penelitian ini adalah 55 orang.

Uji instrumen penelitian dengan uji validitas dan reliabilitas. Teknik analisis data yang digunakan dalam penelitian ini adalah analisis kuantitatif. Dalam penelitian ini analisis yang digunakan untuk mengetahui pengaruh motivasi kerja, kompetensi dan kompensasi terhadap kinerja anggota Kepolisian di unit kerja Polres Kapuas.Analisis data dengan analisa regresi linier berganda dengan menggunakan bantuan SPSS 17 (Duwi Priyatno, 2009). Selain itu juga dilakukan uji F statistik untuk mengetahui pengaruh variabel Independen (X1, X2, X3) secara simultan terhadap variabel dependen $(\mathrm{Y})$ dan uji $\mathrm{t}$ statistik untuk menguji pengaruh antara variabel independen $(\mathrm{X} 1, \mathrm{X} 2, \mathrm{X} 3)$ terhadap variabel dependen $(\mathrm{Y})$ secara parsial, dengan mengasumsikan bahwa variabel lain dianggap konstan.

\section{Hasil Penelitian dan Pembahasan}

Jumlah responden sebanyak 55 orang yang diambil dari satuan-satuan tugas di lingkungan Polres Kapuas Kalimantan Tengah, dibagi menurut pangkat, yaitu :

\section{Tabel 2. Kepangkatan Responden Di Unit Kerja Polres Kapuas Kalimantan Tengah}

\begin{tabular}{clcc}
\hline No & \multicolumn{1}{c}{ Pangkat } & Jumlah & Persentase \\
\hline 1. & Bripda & 15 & $27.3 \%$ \\
\hline 2. & Briptu & 12 & $21.8 \%$ \\
\hline 3. & Brigadir & 18 & $32.7 \%$ \\
\hline 4. & Bripka & 10 & $18.2 \%$ \\
\hline & Total & 55 & $100.0 \%$ \\
\hline
\end{tabular}

Berdasarkan Tabel 2, diketahui responden penelitian kebanyakan berpangkat Brigadir, yaitu 18 orang $(32.7 \%)$, Bripda sebanyak 15 orang (27.3\%), Briptu sebanyak 12 orang (21.8\%), dan Bripka sebanyak 10 orang (18.2\%).

Tabel 3. Kesatuan Tugas Responden Di Unit Kerja Polres Kapuas Kalimantan Tengah

\begin{tabular}{clrc}
\hline No & \multicolumn{1}{c}{ Satuan Tugas } & Jumlah & Persentase \\
\hline 1. & Satintelkam & 8 & $14.5 \%$ \\
\hline 2. & Satreskrim & 15 & $27.3 \%$ \\
\hline 3. & Satresnarkoba & 9 & $16.4 \%$ \\
\hline 4. & Satbinmas & 12 & $21.8 \%$ \\
\hline 5. & Satlantas & 11 & $20.0 \%$ \\
\hline & Total & 55 & $100.0 \%$ \\
\hline
\end{tabular}


Berdasarkan Tabel 3, diketahui responden penelitian terbanyak bertugas di Satreskrim 15 orang (27.3\%), Satbinmas 12 orang (21.18\%), Satlantas 11 orang (20.0\%), dan Satintelkam 8 orang $(14.5 \%)$.

Tabel 4. Jenis Kelamin Responden Di Unit Kerja Polres Kapuas Kalimantan Tengah

\begin{tabular}{clcc}
\hline No & \multicolumn{1}{c}{ Jenis Kelamin } & Jumlah & Persentase \\
\hline 1. & Laki-Laki & 45 & $81.8 \%$ \\
\hline 2. & Perempuan & 10 & $18.2 \%$ \\
\hline & Total & 55 & $100.0 \%$ \\
\hline
\end{tabular}

Berdasarkan Tabel 4, diketahui responden penelitian terbanyak berjenis kelamin lakilaki, yaitu 45 orang $(81.8 \%)$, dan perempuan 10 orang $(18.2 \%)$.

\section{Tabel 5. Status Perkawinan Responden Di Unit Kerja Polres Kapuas Kalimantan}

\section{Tengah}

\begin{tabular}{clcc}
\hline No & \multicolumn{1}{c}{ Status Perkawinan } & Jumlah & Persentase \\
\hline 1. & Kawin & 38 & $69.1 \%$ \\
\hline 2. & Belum Kawin & 17 & $30.9 \%$ \\
\hline & Total & 55 & $100.0 \%$ \\
\hline
\end{tabular}

Berdasarkan Tabel 5. diketahui responden penelitian terbanyak sudah kawin, yaitu 38 orang $(69.1 \%)$, dan yang belum kawin sebanyak 17 orang $(30.9 \%)$.

Selanjutnya adalah uji reliabilitas. Memastikan reliabilitas suatu instrumen penelitian dengan memperhatikan syarat umum dalam statistik dimana reliabilitas suatu konstruk variabel dikatakan baik jika memiliki nilai Alpha Cronbach >0,60. Hasil Pengujian seperti Tabel 6.

Tabel 6. Uji Reliabiltas variabel

\begin{tabular}{lcccr}
\hline \multicolumn{1}{c}{ Variables } & Cronbach's Alpha & Pengujian & N of Items \\
\hline Motivasi Kerja & 0,998 & $>0,60$ (Reliabel) & 10 \\
\hline Kompetensi & 0,994 & $>0,60$ (Reliabel) & 10 \\
\hline Kompensasi & 0,996 & $>0,60$ (Reliabel) & 10 \\
\hline Kinerja & 0,991 & $>0,60$ (Reliabel) & 10 \\
\hline
\end{tabular}

Tabel 7. Uji validitas variabel

\begin{tabular}{lcccccccc}
\hline \multirow{2}{*}{$\begin{array}{c}\text { Item } \\
\text { kuesioner }\end{array}$} & \multicolumn{2}{c}{ Motovasi } & \multicolumn{2}{c}{ Kompetensi } & \multicolumn{2}{c}{ Kompensasi } & \multicolumn{2}{c}{ Kinerja } \\
\cline { 2 - 8 } & $\begin{array}{c}\text { Pearson } \\
\text { Corr }\end{array}$ & $\begin{array}{c}\text { Sig (2 } \\
\text { tailed) }\end{array}$ & $\begin{array}{c}\text { Pearson } \\
\text { Corr }\end{array}$ & $\begin{array}{c}\text { Sig (2 } \\
\text { tailed) }\end{array}$ & $\begin{array}{c}\text { Pearson } \\
\text { Corr }\end{array}$ & $\begin{array}{c}\text { Sig (2 } \\
\text { tailed) }\end{array}$ & $\begin{array}{c}\text { Pearson } \\
\text { Corr }\end{array}$ & $\begin{array}{c}\text { Sig (2 } \\
\text { tailed) }\end{array}$ \\
\hline Kuesioner 1 & $0,970^{* *}$ & 0,000 & $0,991^{* *}$ & 0,000 & $0,957^{* *}$ & 0,000 & $0,978^{* * *}$ & 0,000 \\
\hline Kuesioner 2 & $0,998^{* *}$ & 0,000 & $0,967^{* * *}$ & 0,000 & $0,986^{* *}$ & 0,000 & $0,978^{* *}$ & 0,000 \\
\hline Kuesioner 3 & $0,998^{* *}$ & 0,000 & $0,972^{* *}$ & 0,000 & $0,986^{* *}$ & 0,000 & $0,978^{* *}$ & 0,000 \\
\hline Kuesioner 4 & $0,998^{* *}$ & 0,000 & $0,967^{* *}$ & 0,000 & $0,989^{* *}$ & 0,000 & $0,956^{* *}$ & 0,000 \\
\hline Kuesioner 5 & $0,998^{* *}$ & 0,000 & $0,991^{* *}$ & 0,000 & $0,957^{* *}$ & 0,000 & $0,956^{* *}$ & 0,000 \\
\hline Kuesioner 6 & $0,970^{* *}$ & 0,000 & $0,967^{* *}$ & 0,000 & $0,986^{* *}$ & 0,000 & $0,978^{* *}$ & 0,000 \\
\hline Kuesioner 7 & $0,998^{* *}$ & 0,000 & $0,972^{* *}$ & 0,000 & $0,957^{* *}$ & 0,000 & $0,978^{* *}$ & 0,000 \\
\hline Kuesioner 8 & $0,998^{* *}$ & 0,000 & $0,967^{* *}$ & 0,000 & $1,000^{* *}$ & 0,000 & $0,978^{* *}$ & 0,000 \\
\hline Kuesioner 9 & $0,998^{* *}$ & 0,000 & $0,972^{* *}$ & 0,000 & $0,957^{* *}$ & 0,000 & $0,956^{* *}$ & 0,000 \\
\hline Kuesioner 10 & $0,998^{* *}$ & 0,000 & $0,967^{* *}$ & 0,000 & $0,989^{* *}$ & 0,000 & $0,956^{* *}$ & 0,000 \\
\hline Kuesioner 11 & - & - & - & - & - & - & $0,956^{* *}$ & 0,000 \\
\hline Kuesioner 12 & - & - & - & - & - & - & $0,956^{* *}$ & 0,000 \\
\hline ** Correlation is significant at the 0.01 & level $(2-t a i l e d)$ & & & &
\end{tabular}


Selanjutnya adalah uji validitas instrumen. Pengujian validitas dalam penelitian ini menggunakan analisa item, yaitu dengan mengkorelasikan skor setiap item pertanyaan dengan skor total sebagai jumlah dari skor item. Teknik korelasi yang digunakan adalah teknik korelasi pearson product moment pada tingkat signifikan $95 \%(\alpha=0,05)$. Syarat signifikansi apabila $\boldsymbol{r}_{\text {hitung }}>0,3$ maka disimpulkan bahwa item pertanyaan adalah valid. Hasil uji validitas disajikan seperti Tabel 7.

Langkah selanjutnya adalah melakukan Uji Asumsi Klasik. Tahapan-tahapan yang dibutuhkan dalam uji asumsi klasik meliputi:

1. Uji Normalitas

Uji normalitas dilakukan untuk mengetahui apakah variabel dependen dan variabel indipenden berdistribusi normal atau tidak. Model regresi yang baik memiliki distribusi data normal atau mendekati normal. Dari Gambar 1. Grafik normal PP Plot sebaran titiktitik mendekati garis diagonal regresi maka dapat disimpulkan variabel motivasi kerja, kompetensi, Kompensasi dan kinerja data, berdistribusi normal.
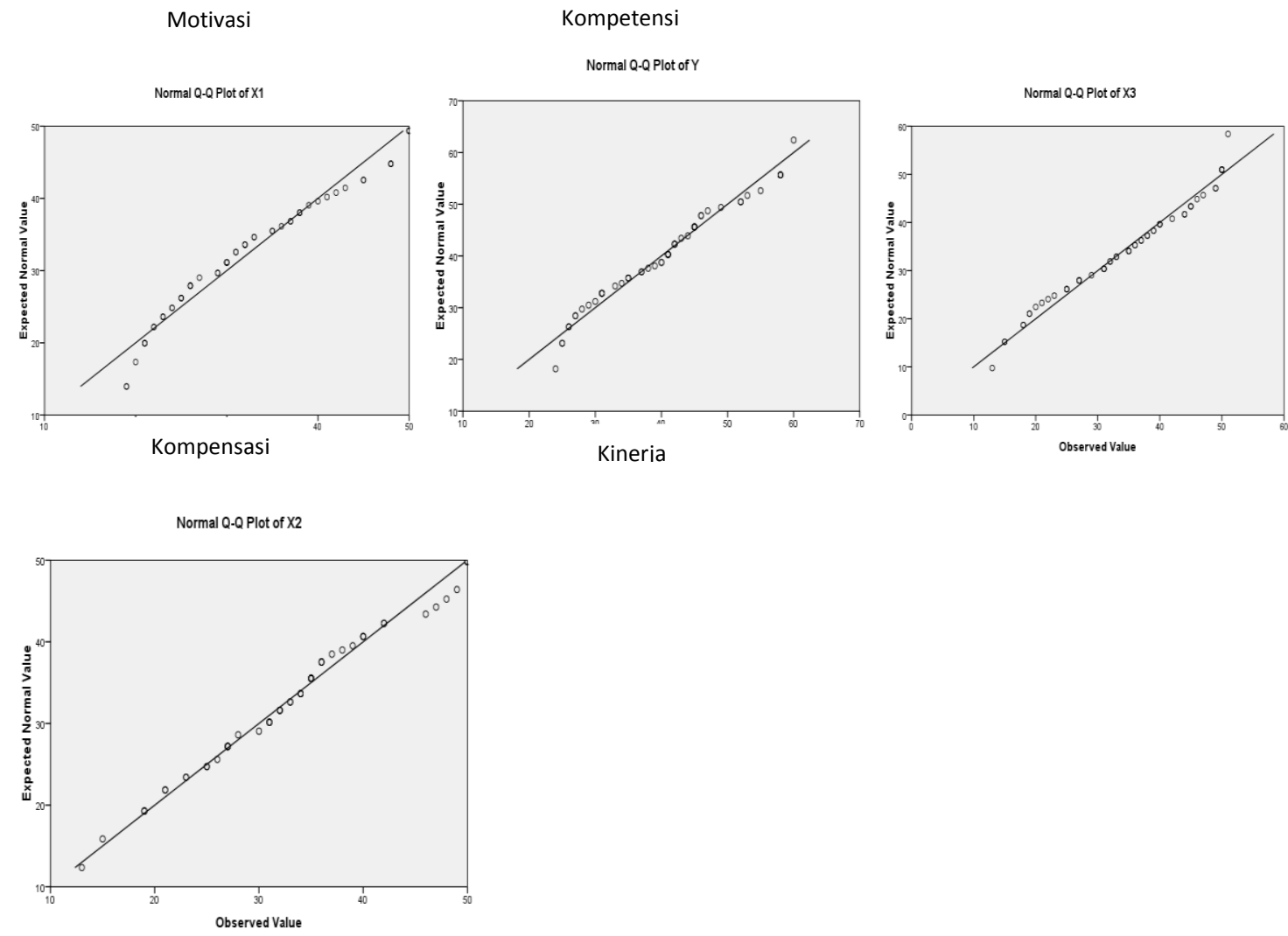

\section{Gambar 1. Uji Normalitas Data}

\section{Uji Linearitas}

Uji Linearitas. Berdasarkan Tabel 8, uji linieritas disimpulkan bahwa variabel motivasi kerja (X1) linier terhadap variabel kinerja $(\mathrm{Y})$, dimana sifat yang linier dengan nilai $\mathrm{F}$ 56.039 atau Sig 0.000, variabel kompetensi (X2) linier terhadap variabel kinerja (Y), dimana sifat yang linier dengan nilai $F 46.796$ atau Sig 0.000. dan variabel kompensasi (X3) linier terhadap variabel kinerja (Y), dimana sifat yang linier dengan nilai F 21.041 atau Sig 0.000 . 
Tabel 8. Uji Linieritas Variabel X1,X2 X3 Terhadap Variabel Y

\begin{tabular}{lllrr}
\hline & & \multicolumn{1}{c}{$\mathrm{F}$} & \multicolumn{1}{c}{ Sig. } \\
\hline $\mathrm{Y}{ }^{*} \mathrm{X} 1$ & Between & \multicolumn{1}{c}{ (Combined) } & 2.949 & .003 \\
\cline { 3 - 5 } Groups & & Linearity & 56.039 & .000 \\
\cline { 3 - 5 } & & Deviation from Linearity & .737 & .776 \\
\hline $\mathrm{Y}^{*} \mathrm{X} 2$ & \multirow{2}{*}{ Between } & (Combined) & 3.145 & .002 \\
\cline { 3 - 5 } Groups & & Linearity & 46.796 & .000 \\
\cline { 3 - 5 } & & Deviation from Linearity & 1.326 & .232 \\
\hline $\mathrm{Y} * \mathrm{X} 3$ & \multirow{2}{*}{ Between } & (Combined) & 1.714 & .084 \\
\cline { 3 - 5 } Groups & & Linearity & 21.041 & .000 \\
\cline { 3 - 5 } & & Deviation from Linearity & .971 & .529 \\
\hline
\end{tabular}

Uji Heteroskedastisitas, dilakukan dengan melihat grafik scatterplot, dimana jika terdapat titik-titk yang menyebar secara acak (random) baik di atas maupun di bawah angka nol pada sumbu $\mathrm{Y}$ dapat disimpulkan bahwa tidak terjadi heteroskedastisitas pada model regresi (Ghozali,2005 : 125). Berdasarkan Gambar 2.di bawah maka dapat disimpulkan tidak terjadi heteroskedastisitas.

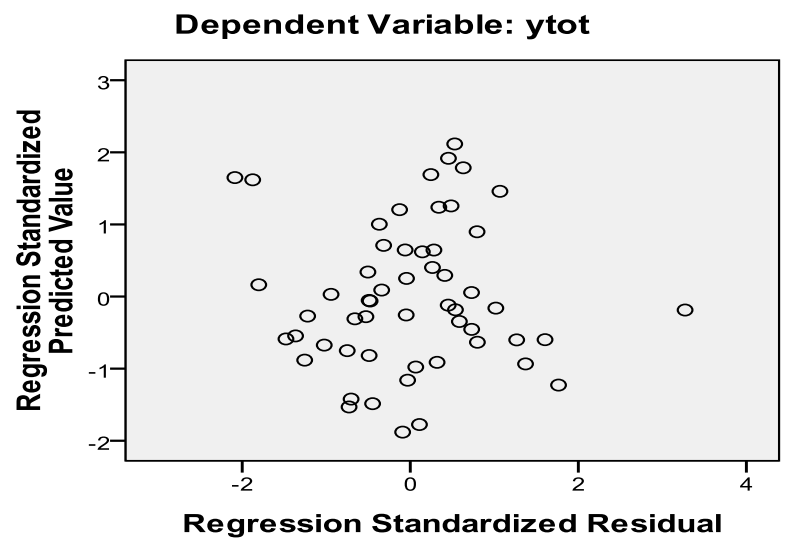

\section{Gambar 2. Grafik Scatterplot}

3. Uji Multikolinearitas

Untuk mendeteksi ada atau tidaknya multikolinearitas dapat dilakukan dengan mengukur nilai Tolerance dan menguji Variance Inflation Factor (VIF). Suatu model regresi yang bebas dari multikolinieritas adalah jika mempunyai nilai VIF kurang dari 10 dan nilai Tolerance Value > 0,10 (Ghozali, 2005: 124). Hasil pengujian multikolinearitas seperti Tabel 9 di bawah,seluruh variabel bebas yang diteliti memiliki nilai Tolerance $>0,10$ dan nilai $V I F<10,00$. Jadi dapat disimpulkan bahwa tidak ada multikolinearitas antar variabel independen dalam model regresi.

Tabel 9. Hasil uji Multikolinieritas

\begin{tabular}{clcc}
\hline \multirow{2}{*}{ No } & \multicolumn{1}{c}{ Variabel } & \multicolumn{2}{c}{ Collinearity Statistic - Kota } \\
\cline { 3 - 4 } & & Tolerance & VIF \\
\hline 1 & Motivasi kerja & $0,666>0,10$ & $1,500<10,00$ \\
\hline 2 & Kompetensi & $0,506>0,10$ & $1,975<10,00$ \\
\hline 3 & Kompensasi & $0,565>0,10$ & $1,525<10,00$ \\
\hline
\end{tabular}


Langkah selanjutnya adalah analisis regresi berganda. Memprediksi pengaruh variabel independen : motivasi kerja, kompetensi dan kompensasi terhadap kinerja, dilakukan dengan analisis regresi linear berganda, digambarkan seperti tabel 10.

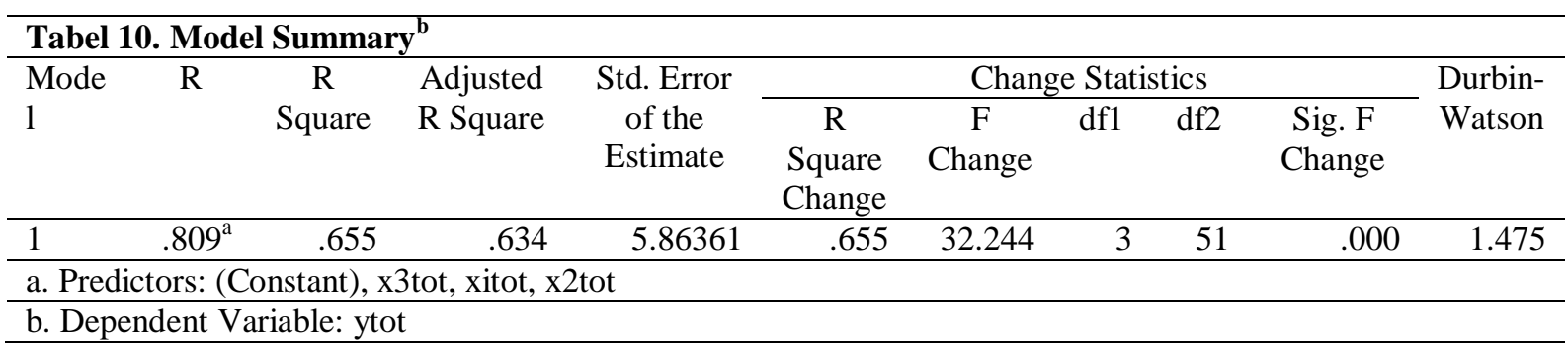

Tabel 10 menunjukkan bahwa kinerja dapat dijelaskan oleh variabel motivasi kerja, kompetensi dan kompensasi sebesar 65,5\% ( $R$ Square), sementara sisanya yakni 34,5\% dijelaskan oleh variabel lain di luar variabel penelitian ini.

Tabel 11. Hasil Uji Signifikan F

\begin{tabular}{|c|c|c|c|c|c|c|}
\hline \multicolumn{7}{|c|}{ ANOVA $^{b}$} \\
\hline & Model & Sum of Squares & df & $\begin{array}{l}\text { Mean } \\
\text { Square }\end{array}$ & $\mathrm{F}$ & Sig. \\
\hline \multirow[t]{3}{*}{1} & Regression & 3326.734 & 3 & 1108.911 & 32.269 & $.000^{\mathrm{a}}$ \\
\hline & Residual & 1752.611 & 51 & 34.365 & & \\
\hline & Total & 5079.345 & 54 & & & \\
\hline
\end{tabular}

Tabel 12. Coeffeicients

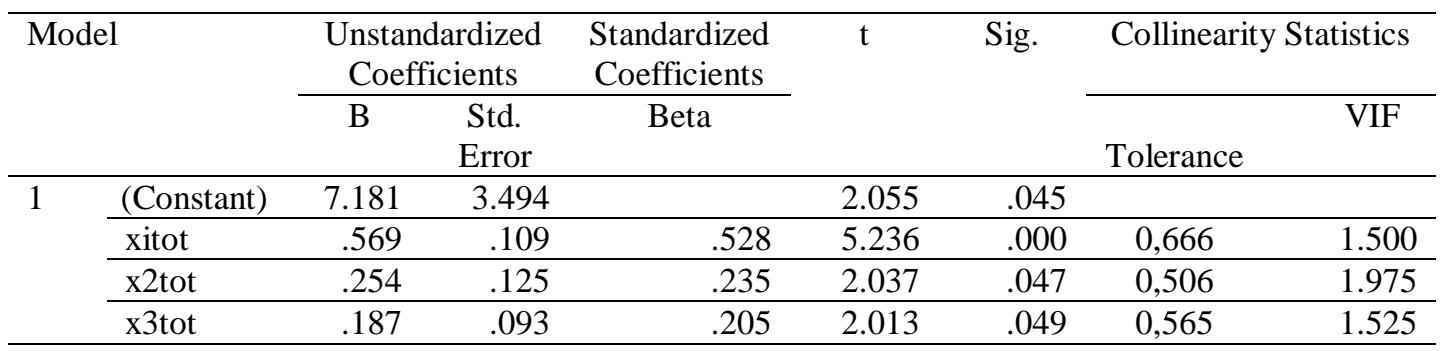

Berdasarkan Tabel 12. dapat disusun persamaan regresi sebagai berikut :

$Y=a+b_{1} X_{1}+b_{2} X_{2}+b_{3} X_{3}+e$

$Y=7,181+0,569 X_{1}+0,254 X_{2}+0,187 X_{3}+e$

Penjelasan :

1. Nilai konstanta sebesar 7.181, artinya apabila motivasi kerja, kompetensi dan kompensasi diasumsikan nol (0), maka kinerja karyawan bernilai 7.178.

2. Angka koefisien regresi X1 $=0.569$, artinya kalau variabel lain konstan, maka setiap peningkatan motivasi kerja sebesar 1 satuan maka akan meningkatkan kinerja sebesar 0.569 satuan.

3. Angka koefisien regresi $\mathrm{X} 2=0.254$, artinya kalau variabel lain konstan, maka setiap peningkatan kompetensi sebesar 1 satuan maka akan meningkatkan kinerja sebesar 0.254 satuan. 
4. Angka koefisien regresi $\mathrm{X} 3=0.187$, artinya setiap peningkatan kompensasi sebesar 1 satuan maka akan meningkatkan kinerja sebesar 0.187 satuan.

Dari hasil peneltian ini, dapat disusun pembuktian atas hipotesis yang telah diajukan sebelumnya, yaitu sebagai berikut:

1. Hasil uji F seperti Tabel 11 di atas, menunjukan nilai $F_{\text {hitung }}=32.269$ dan $\mathrm{Sig}=0,000<$ 0,05, maka dapat dinyatakan motivasi kerja (X1), kompetensi (X2), dan kompensasi (X3) berpengaruh secara bersama-sama (simultan) terhadap kinerja anggota Kepolisian di unit Polres Kapuas Provinsi Kalimantan Tengah. Dengan demikian hipotesis 1 dapat dibuktikan.

2. Uji $\mathrm{t}$ (parsial) sperti Tabel 12, diperoleh hasil $t_{\text {hitung }}$ variabel :

- Motivasi kerja (X1) $\mathrm{t}_{\text {hitung }} 5,236$ dan sig $p=0,000<0,05$ adalah signifikan

- Komoetensi (X2) $\mathrm{t}_{\text {hitung }} 2,037$ dan sig $p=0,047<0,05$. adalah signifikan

- Kompensasi (X3) $\mathrm{t}_{\text {hitung }} 2,013$ dan sig $p=0,049<0,05$. adalah signifikan

maka dapat dinyatakan secara parsial variabel motivasi kerja, kompetensi, dan kompensasi berpengaruh signifikan terhadap kinerja. Dengan demikian hipotesis 2, dinyatakan terbukti.

3. Berdasarkan persamaan regresi di atas dengan membandingkan nilai koefisien regresi atau nilai t, maka dapat disimpulkan bahwa motivasi kerja adalah variabel yang berpengaruh dominan terhadap kinerja dan hipotesis 3, terbukti.

Hasil penelitian ini menemukan bahwa motivasi kerja, kompetensi, dan kompensasi berpengaruh secara bersama-sama (simultan) terhadap kinerja anggota Kepolisian di unit Polres Kapuas Provinsi Kalimantan Tengah.

Sebagaimana jawaban responden yang merasa termotivasi dalam bekerja, ada tantangan tugas, bekerja dalam tim yang solid dan kompak di bawah kepercayaan pemimpin, menjadikan suasana kerja yang nyaman dan harmonis. Semakin tinggi motivasi semakin berperan untuk memberikan penguatan (reinforcement) terhadap keinginan-keinginan yang mengarah pada tercapainya prestasi kerja yang semakin baik serta dapat mengarahkan sikap perilaku individu dalam mencapai tujuan.

Para responden merasakan dapat mengelola dan mengatur pekerjaan sehingga tepat waktu dalam penyelesaianya, melakukaan pekerjaan dalam sebuah sistem yang saling mendukung dengan kejelasan tugas dan tanggungjawab sehingga dapat dilaksanakan dengan baik, mampu mengarahkan dan membimbing anggota dan mitra kerja, hal ini karena dimilikinya kompetensi yang memadai dalam mendukung pelaksanaan tugas. Pada sisi lainnya kepuasan terhadap kompensasi yang memadai dan dilaksanakan selalu tepat waktu, didukung kebijakan pengusulan kenaikan gaji sesuai aturan yang berlaku, demikinan juga sistem reward yang dikembangkan sesuai dengan aturan yang berlaku,mendorong para anggota bekerja dengan bersemangat untuk mencapai prestasi yang diharapkan.

Hasil penelitian ini sejalan dengan penelitian yang dilakukan Kristina.N (2012),yang menyatakan secara simultan semua variabel bebas berpengaruh signifikan terhadap variabel terikat dengan nilai sig. $0,000<\alpha 0,05$. Pengaruh yang diberikan ketiga variabel bebas tersebut bersifat positif artinya semakin tinggi motivasi kerja, kompetensi dan kompensasi maka semakin tinggi pula kinerja karyawan yang dihasilkan.

Agar institusi Kepolisian mendapatkan suatu pengakuan yang lebih baik dimata masyarakat dengan segala kegiatan-kegiatan dilakukan untuk mencapai tujuan yang diinginkan dengan menggunakan sumber daya manusia yang tersedia, tetapi untuk mencapai tujuan tersebut tidak cukup hanya dengan jalan memperoleh anggota yang dianggap paling kompeten, akan tetapi tidak kalah pentingnya dengan secara terus menerus pimpinan 
memberikan motivasi dan kompensasi kepada anggotanya agar lebih bersemangat dalam menjalankan tugas-tugasnya di kesatuannya masing-masing.

Implikasi dari hasil penelitian ini, kinerja anggota Kepolisian di unit Polres Kapuas Provinsi Kalimantan Tengah dapat ditingkatkan melalui peningkatan motivasi kerja, kompetensi dan kompensasi.

Hasil penellitian ini menemukan bahwa secara parsial variabel motivasi kerja, kompetensi dan kompensasi berpengaruh signifikan terhadap kinerja.

1. Jawaban responden terhadap variabel motivasi berpengaruh positif dan sinifikan bahwa motivasi kerja yang baik maka anggota Kepolisian akan memberikan kinerja yang baik pula.para responden merasa termotivasi dalam bekerja, ada tantangan tugas, bekerja dalam tim yang solid dan kompak di bawah kepercayaan pimpinan, menjadikan suasana kerja yang nyaman dan harmonis. Semakin tinggi motivasi semakin berperan untuk memberikan penguatan (reinforcement) terhadap keinginan-keinginan yang mengarah pada tercapainya prestasi kerja yang semakin baik serta dapat mengarahkan sikap perilaku individu dalam mencapai tujuan. Sehingga motivasi kerja yang baik akan membuat anggota Kepolisian di unit Polres Kapuas Provinsi Kalimantan Tengah akan meningkatkan kinerjanya.

Motivasi merupakan sebuah keahlian dalam mengarahkan karyawan pada tujuan organisasi agar mau bekerja dan berusaha sehingga keinginan para karyawan dan tujuan organisasi dapat tercapai. Motivasi seseorang melakukan suatu pekerjaan karena adanya suatu kebutuhan hidup yang harus dipenuhi. Kebutuhan ini dapat berupa kebutuhan ekonomis yaitu untuk memperoleh uang. Sedangkan kebutuhan nonekonomis dapat diartikan sebagai kebutuhan untuk memperoleh penghargaan dan keinginan lebih maju. Dengan segala kebutuhan tersebut, seseorang dituntut untuk lebih giat dan aktif bekerja, untuk mencapai hal ini diperlukan adanya motivasi dalam melakukan pekerjaan, karena dapat mendorong seseorang bekerja dan selalu berkeinginan untuk melanjutkan usahanya.

Hasil penelitian ini mendukung hasil penelitian Mustamil (2008) bahwa motivasi berpengaruh positif dan signifikan terhadap kinerja pegawai di Kantor Departemen Agama Kabupaten Boyolali. Hasil penelitian ini juga sesuai dengan hasil penelitian yang dilakukan Abayomi (2014) menemukan bahwa motivasi kerja ditemukan memiliki pengaruh positif terhadap karyawan di perusahaan. Demikian juga Hasil penelitian ini sependapat dengan Sudarwati (2014), dimana pada penelitiannya menemukan motivasi kerja mempunyai pengaruh positif dan signifikan terhadap kinerja Pegawai di Dinas Pendidikan Kabupaten Sragen.

2. Demikian juga dengan variabel kompetensi mempunyai pengaruh positif dan signifikan terhadap kinerja anggota Kepolisian di unit Polres Kapuas Provinsi Kalimantan Tengah, berarti apabila kompetensi semakin ditingkatkan maka kinerja anggota akan semakin meningkat. Kinerja dan keefektifan Anggota Kepolisian dalam melaksanakan tugas pada kesatuannya masing-masing sangat ditentukan oleh kompetensi yang disyaratkan oleh bidang pekerjaan. Melalui kompetensi yang semakin memadai seseorang akan lebih menguasai dan mampu menerapkan secara praktek semua tugas pekerjaan sesuai dengan job description yang ditetapkan. Kompetensi anggota yang semakin tinggi dapat diukur dari semakin bertambahnya pengetahuan dan keterampilan serta semakin berkembangnya perangai/sifat dan konsep diri yang semakin baik.

Hasil penelitian mendukung penelitian yang dilakukan Nugroho (2006) bahwa kompetensi berpengaruh positif dan signifikan terhadap kinerja pegawai di Kantor Pertanahan Kota Semarang. Penelitian ini juga mendukung penelitian Marjoko (2009) bahwa kompetensi berpengaruh positif dan signifikan terhadap kinerja pegawai di lingkungan Sekretariat Dewan Perwakilan Rakyat Daerah. Implikasi dari hasil penelitian ini, kinerja anggota Kepolisian di unit Polres Kapuas Provinsi Kalimantan Tengah dapat ditingkatkan melalui peningkatan kompetensi. 
3. Variabel kompensasi, dalam penelitian ini juga mempunyai pengaruh terhadap peningkatan kinerja. Kompensasi merupakan sesuatu yang diterima anggota Kepolisian sebagai pengganti kontribusi jasa mereka pada institusi Kepolisian. Kompensasi juga sebagai faktor penting dalam upaya meningkatkan kinerja anggota Kepolisian dan sebagai perangsang dalam mendorong anggota agar tugas-tugas yang dibebankan oleh kesatuannya tercapai. Penerapan sistem kompensasi yang baik akan membuat anggota merasa dihargai sehingga mereka akan termotivasi dalam bekerja, yang pada akhirnya berdampak pada kinerjanya.

Hasil penelitian ini medukung penelitian sebelumnya yang dilakukan oleh Aji (2015) yang menganalisis tentang pengaruh lingkungan kerja, disiplin kerja, dan kompensasi terhadap kinerja karyawan perusahaan percetakan Masscom Graphy Semarang. Pada penelitian ini menyatakan bahwa variabel kompensasi mempengaruhi kinerja karyawan secara signifikan. Semakin baik kompensasi yang diberikan maka akan semakin baik pula kinerjanya.

\section{Kesimpulan}

Berdasarkan hasil analisis dan pembahasan analisis pengaruh motivasi kerja, kompetensi dan kompensasi terhadap kinerja anggota Kepolisian di unit kerja Polres Kapuas Provinsi Kalimantan Tengah, disimpulkan:

1. Motivasi kerja, kompetensi, dan kompensasi berpengaruh signifikan secara simultan terhadap kinerja anggota Kepolisian di unit kerja Polres Kapuas Provinsi Kalimantan Tengah.

2. Motivasi kerja, kompetensi, dan kompensasi berpengaruh signifikan secara parsial terhadap kinerja anggota Kepolisian di unit kerja Polres Kapuas Provinsi Kalimantan Tengah.

3. Motivasi kerja berpengaruh dominan terhadap kinerja anggota Kepolisian di unit kerja Polres Kapuas Provinsi Kalimantan Tengah.

\section{DAFTAR PUSTAKA}

Adeoye, 2014, Compensation Management and Motivation : Cooking Utensils for OrganisationalPerformance.Mediterranea Journal of Social Sciences 5 (27).

Aji, O.P. 2015. Pengaruh Lingkungan Kerja, Disiplin Kerja, dan Kompensasi Terhadap Kinerja Karyawan PT Masscom Graphy Semarang. Jurnal. Ilmu Administrasi Bisnis Universitas Diponegoro. Vol 4. N0 2.

Anastasia. T, 2013. Pengaruh Motivasi Kerja Dan Kepuasan Kerja Terhadap Komitmen Organisasional Karyawan PT DAI KNIFE Di Surabaya. Tesis. Program Manajemen Bisnis, Program Studi Manajemen, Universitas Kristen Petra.

Arie, Harliman, Lorens. 2007. Pengaruh Motivasi, Kemampuan dan Kepuasan kerja terhadap kinerja karyawan pada PT Multi Structure Sarana.

Arikunto. S.1998. Prosedur Penelitian Suatu Pendekatan Praktek. Jakarta : Rineka Cipta.

Becker, Brian E., et al. 2009. The HR Scorecard, Mengaitkan Manusia, Stategi dan Kinerja. PT Gelora Aksara Pratama, Jakarta.

Budiarto, E. 2009. Biostatistik Untuk Kedokteran dan Kesehatan Masyarakat. Jakarta, EGC.

Dessler. Gary, 2006. Manajemen Sumber Daya Manusia. Edisi ke sepuluh. Klaten, PT. Intan Sejati.

Endang. Ilyas. 2011.Pengaruh Kompensasi, Promosi dan Shift Kerja terhadap Kepuasan Kerja dan Kinerja Pengumpul Tol Gerbang Karang Tengah dan Ramp. Kebun Jeruk.

Ghozali, Imam.H, 2005. Analisis Multivariate dengan Program SPSS Eddisi 3 .Semarang, Badan Penerbit Universitas Diponegoro.

Gibson, Ivancevich dan Donnely, 2004. Organisasi . Jakarta, PT Erlangga. 
Soemantri \& Sjamsi, Analisis Pengaruh Motivasi Kerja, Kompetensi, dan Kompensasi Terhadap Kinerja

Gibson, 2007. Fundamental of Management. 10th Edition Mc Grow Hill.

Gomes, 2010. Manajemen Sumber daya Manusia . Yogyakarta, Andi Ofset.

Gordon, Anderson. 1992. Managing Performance Appraisal System . UK. Strathclyde Business school.

Gouzali Saydan, 2009. Manajemen Sumber daya Manusia . Djambatan.

Hadi. Agung. 2007. Kompetensi, Motivasi, peran Kepemimpinan, dan Kinerja pegawai direktorat jenderal Perdagangan dalam negeri.

Hani. Handoko. 2003. Manajemen Sumber Daya Manusia. Jakarta, Salemba Medika.

Hasibuan, Malayu. 2007. Organisasi dan Motivasi. Jakarta, PT. Bumi Aksara.

Husein Umar, 2002. Metode Riset Bisnis, PT. Gramedia Pustaka Utama, Jakarta.

John M. Echols dan Hasan Shadily,1975. An English-Indonesian Dictionary. Cornell University Press, New York 14850. Edisi bahasa Indonesia, 1996. PT Gramedia Pusaka Utama. Jakarta.

Malayu S.P. Hasibuan, 2003. Manajemen Sumber Daya Manusi. Jakarta, Salemba Empat.

Malthis, R. L. dan Jackson, 2001. Manajemen Sumber Daya Manusia, Jakarta, Salemba Empat.

Mangkunegara, 2009. Manajemen Sumber daya Manusia dan Perusahaan. Bandung. Roasdakarya.

Mangkuprawira, Tb. Sjafri. 2009. Bisnis, Manajemen, dan Sumberdaya Manusia.Bogor, IPB Press.

Misail Palagia, 2014. Remunerasi, Motivasi, dan Kepuasan Kerja Terhadap Kinerja Pegawai Kantor Pajak. Tesis. Program Magister manajemen. Unhas Makasar.

M. Manulang, 1994. Manajemen Personalia. Ghalia Indonesia, Jakarta.

Mondy Wayne. R., 2008. Manajemen Sumber Daya Manusia untuk Perusahaan. Jakarta, Rajawali Pers.

Mulyana, 2007. Proporsionalitas Pengetahuan dan Pemahaman Anggota Polri Yang Berada Di Lini Terdepan Pelayanan Kepolisian Pada Paradigma Fungsi, Peran Dan Kultur Polri. Bandung, UNPAD.

Muniroh, 2013. Hubungan Antara Kohesivitas Kelompok Dan Motivasi Kerja Karyawan Bri Kantor Cabang Malang Martadinata, Universitas Negeri Malang.

Mustamil, 2008, Pengaruh Motivasi Kerja, Kepemimpinan dan Lingkungan Kerja terhadap Kinerja Pegawai Kantor Departemen Agama Kabupaten Boyolali, Tesis, Program Studi Magister Manajemen, Program Pasca Sarjana Universitas Slamet Riyadi, Surakarta.

Notoatmodjo, S. 2009. Pengembangan Sumber Daya Manusia.Jakarta,PT Rineka Cipta.

Nugroho.S, 2006, Pengaruh Budaya Organisasi, Motivasi Dan Kompetensi Terhadap Kinerja Pegawai Pada Kantor Pertanahan Kota Semarang, Tesis. Program Magister Manajemen,

Sekolah Tinggi Ilmu Ekonomi Stikubank Semarang (Tidak dipublikasikan).

Panggabean. Mutiara.S. 2002. Manajemen Sumber Daya Manusia Jakarta. Ghalia Indonesia.

Ruky.A., 2006. Sistem Manajemen Kinerja, Jakarta. PT. Gramedia.

Rampesad, Hubert K., 2006. Pertajam Kompetensi Anda dengan Personal Balance Scorecard. Sinergikan Ambisi Pribadi dengan Ambisi Perusahaan Anda. PPM. Jakarta.

Rindya, 2012. Analisis Pengaruh Rekrutmen dan Kompetensi Terhadap Kinerja Satpam (Studi Pada Perusahaan Outside Provider PT Bina Area Persada Surabaya. Fakultas Ekonomi dan Bisnis. Malang. Universitas Brawijaya.

Rivai, Veithzal, 2004. Manajemen Sumber Daya Manusia Untuk Perusahaan, Jakarta. PT. Rajagrafindo Persada.

Robbins, Stephen, P. dan Mary Coulter, 2005. Manajemen,Jakarta, PT Indeks kelompok Gramedia.

Ruky, A, 2006. Sumber Daya Manusia yang Berkualitas mengubah Visi menjadi Realitas . Jakarta, PT. Gramedia Pustaka Utama. 
Ruky.A., 2006. Sistem Manajemen Kinerja, Jakarta. PT. Gramedia

Santoso Singgih. 2008. Buku Pelatihan SPSS Statistik Parameter. Jakarta,PT. Elek Media Komputindo.

Sedarmayanti, 2001. Sumber daya Manusia dan Produktivitas Kerja. Bandung, Cv. Mandar maju.

Siagian, Sondang. P. 2002. Kiat Meningkatkan Produktivfitas Kerja. Jakarta, PT. Rineka Cipta.

Simanjuntak, P., 2005. Manajemen dan Evaluasi Kinerja. Lembaga, Jakarta, Penerbit FE UI.

Simamora. H. 2004. Manajemen Sumber Daya Manusia, Jakarta.STIE YKPN.

Sinulingga Hermanto. 2004. Pengaruh Motivasi, Kemampuan dan Kepemimpinan terhadap kinerja pegawai.

Siregar. 2010. Hubungan Antara Outcome-Expetancy Dengan Motivasi Kerja Anggota Polantas Polres Metro Tangerang. Skripsi. Jakarta, UIN.

Soeharyo, S. dan Sofia, 2001. Etika Kepemimpinan Aparatur. Bahan Ajar Diklatpim Tingkat IV. Lembaga Administrasi Negara R.I. Jakarta.

Stoner. James, dan Gilbert. 2003. Manajemen. Jakarta. PT Indeks Gramedia Group.

Sudarwati, 2014, Pengaruh Motivasi, Disiplin Kerja Dan Kompetensi Terhadap Kinerja Pegawai Dinas Pendidikan Kabupaten Sragen. Jurnal Paradigma. Vol 12, no 01.

Sugiyono, 2010, Metode Penelitian Kuantitatif Kualitatif dan R\&D,Jakarta,Alfabeta.

Sumarno. 2009. Pengaruh Kepemimpinan Kepala Sekolah dan Profesionalime Guruterhadap Kinerja Guru Sekolah Dasar Negeri di Kecamatan Paguyangan Kabupaten Brebes. Semarang.

Suparno. 2007. Pengaruh Motivasi Kerja dan Kepemimpinan Situasional Kepala Sekolah Terhadap Kinerja Guru SMP Negeri Di kecamatan Pemalang Kabupaten Pemalang. Tesis. Semarang.

Tika, P., 2006. Budaya Organisasi Dan Peningkatan Kinerja Perusahaan. Jakarta, PT Bumi Aksara. J

Tony Listianto, 2013. Pengaruh Motivasi, Kepuasan, Dan Disiplin Kerja terhadap Kinerja Karyawan (Studi Kasus Di Lingkungan Pegawai Kantor PDAM Kota Surakarta). Tesis. Program Pascasarjana. Universitas Muhammadiyah Surakarta.

Wibowo, 2008. Manajemen Kinerja. Jakarta, PT. Grafindo Persada. 